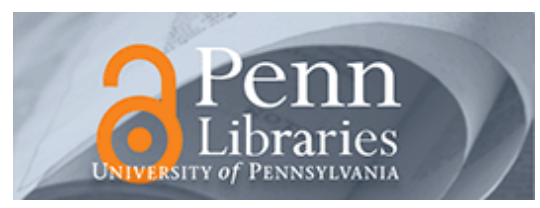

University of Pennsylvania ScholarlyCommons

July 2007

\title{
Parents' Work, Depressive Symptoms, Children, and Family Economic Mobility: What Can Ethnography Tell Us?
}

Roberta R. Iversen

University of Pennsylvania, riversen@sp2.upenn.edu

Annie Laurie Armstrong

Business Government Community Connections

Follow this and additional works at: https://repository.upenn.edu/spp_papers

\section{Recommended Citation}

Iversen, R. R., \& Armstrong, A. (2007). Parents' Work, Depressive Symptoms, Children, and Family Economic Mobility: What Can Ethnography Tell Us?. Retrieved from https://repository.upenn.edu/ spp_papers/82

Reprinted with permission from Families in Society: The Journal of Contemporary Social Services, Volume 88, Issue 3, July 2007, pages 339-350.

Publisher URL: www.familiesinsociety.org.

Published by the Alliance for Children and Families.

This paper is posted at ScholarlyCommons. https://repository.upenn.edu/spp_papers/82

For more information, please contact repository@pobox.upenn.edu. 


\title{
Parents' Work, Depressive Symptoms, Children, and Family Economic Mobility: What Can Ethnography Tell Us?
}

\author{
Abstract \\ Low-income work, job training, depressive symptoms or depression, and children's school performance. \\ These topics have occupied the attention of scholars and policy makers in recent years, particularly as \\ they pertain to single mothers in the context of welfare reform. Broadening this landscape, findings from \\ longitudinal, multi-city ethnographic research reveal that low-income fathers also experience depression \\ or depressive symptoms that hinder family economic mobility. Further, repeated scores from a \\ community-based depressive symptoms measure embedded in the ethnographic inquiry show that the \\ timing of parents' training and employment pathways, economic conditions, and policies in firms and \\ children's schools intersect with parents' depressive symptoms or depression to affect mobility. Program \\ and policy supports seem to mediate these intersecting mobility challenges.

\section{Comments} \\ Reprinted with permission from Families in Society: The Journal of Contemporary Social Services, Volume \\ 88, Issue 3, July 2007, pages 339-350. \\ Publisher URL: www.familiesinsociety.org. \\ Published by the Alliance for Children and Families.
}




\title{
Parents' Work, Depressive Symptoms, Children, and Family Economic Mobility: What Can Ethnography Tell Us?
}

\author{
Roberta Rehner Iversen \& Annie Laurie Armstrong
}

\begin{abstract}
Low-income work, job training, depressive symptoms or depression, and children's school performance. These topics have occupied the attention of scholars and policy makers in recent years, particularly as they pertain to single mothers in the context of welfare reform. Broadening this landscape, findings from longitudinal, multicity ethnographic research reveal that low-income fathers also experience depression or depressive symptoms that hinder family economic mobility. Further, repeated scores from a community-based depressive symptoms measure embedded in the ethnographic inquiry show that the timing of parents' training and employment pathways, economic conditions, and policies in firms and children's schools intersect with parents' depressive symptoms or depression to affect mobility. Program and policy supports seem to mediate these intersecting mobility challenges.
\end{abstract}

\section{The H. W. Blessed Family Story}

n August 2000, 40-year-old Milwaukee resident H. W. Blessed (self-selected pseudonym), took a new job as a forklift operator and supply handler at Printing Company. His starting wage was $\$ 12$ per hour, but he expected to work about eight hours a week overtime at $\$ 18$ per hour for $\$ 624$ a week, a bit over his top earnings (\$600/week) at Steel Mill \& Foundry, the firm he worked for after attending a manufacturing skills training program in 1998 but where he'd been injured and thus demoted, as his supervisor related:

The company has to worry about your condition . . . The company is liable if anything happens to you. And once you're transferred even if you have a doctor's certificate saying that you can return, the position may be filled. (Steel Mill \& Foundry, Second Shift Foreman, Milwaukee)
Mr. Blessed expected wage progression more than skill development or promotion in his new position, but he hoped that the new work environment would contribute to family serenity. However, the final months at Steel Mill \& Foundry, and working 12-hour shifts at Printing Company, caused his wife and him considerable strain, as both reported:

Mr. Blessed: At Printing Company I'd go to work, come home, eat, and pass out. Then I'd get up, go to work, and do the same thing. I'm much happier now [at the job after Printing Company] —all the way around. I can breathe now. I'm not so tired when I come in. I have a pleasant look on my face. I'm not dead. I have time with my wife and children and my responsibilities.

Mrs. Blessed: During the last months at Printing Company, H. W. put the weight of the family problems on his shoulders. It tears him up. He didn't shave; he didn't cut his hair. 
The parents' stress also reached the children. When Mr. Blessed regained custody of his adolescent son a couple of years earlier, rescuing him from a life-threatening urban environment, his son's academic performance improved dramatically. However, the son's progress was interrupted by his father's serious injuries at Steel Mill \& Foundry. Instead of the son verbalizing his deep concern about his father's safety-typical of teens, but perhaps also because he and his father had only recently been reunited-the son's grades plunged. His teachers then increased their demands for parent conferences, which meant that the parents lost wages because their firms had no official "time off" policy. These stresses seemed to exacerbate the depressive symptoms of both the mother and father. A recurrence of seizures forced Mrs. Blessed to resign from her nursing aide job and return to the TANF rolls.

Mr. Blessed's job-induced downward spiral also resulted in a common but inadequate policy response. During the period that he was unemployed and on probation at Printing Company, the family's child care subsidy phased out because it was set according to his previous income level. To make ends meet, the parents moved 3-year-old Baby Miracle from a certified, developmental child care center to what they characterized as less adequate in-home child care, as Mrs. Blessed reported:

Baby Miracle's in daycare now through someone we got through my aunt. I don't like it. It's not set up well enough. The house isn't neat. It's home daycare. Baby Miracle is so dirty when I pick her up, even though I've sent along a change of clothes. She's had diaper rash. But it's $\$ 75$ a week which is affordable. A really good facility would be $\$ 185$. That's what the last one cost. I want one where someone will spend time with her; someone who will cultivate her mind. She understands nearly everything. I want a daycare with developmental instruction. (Mrs. Blessed, Milwaukee)

\section{Background and Research Context}

\section{Background}

This excerpt from longitudinal ethnographic research illustrates that mothers' and fathers' job training and employment pathways, conditions and wages in the parents' firms, children's school policies, and parents' depressive symptoms or depression intersect to affect family economic mobility. At present, however, most of what we know about these associations comes from research among women and/or from cross-sectional analyses.

Uniquely, Elder's (1974) analysis of employment during the Great Depression of the 1930s identified the association between unemployment and depression in men. Thereafter, most research on depression and employment was conducted among women welfare recipients. Most recently, in the welfare reform milieu of mandatory work and time-limited benefits, researchers find that depression may prevent single mothers from finding jobs or remaining employed (Ahluwalia, McGroder, Zaslow, \& Hair, 2001; Danziger et al., 1998; Duncan, Dunifon, Doran, \& Yeung, 2001), particularly if the symptoms are compounded by other challenges such as low levels of education, little work experience, transportation or health problems, domestic violence, and correspondingly few mediating program or policy supports (Lennon, Blome, \& English, 2001). Such compounding challenges are common among low-earning workers such as the parents in this study.

We also know that poverty and low incomes are associated with depression and depressive symptoms in parents (Kessler et al., 2003). These associations are particularly worrisome today, as one in four full-time workers earns less than $\$ 9.04$ an hour-a wage that is at or below the poverty threshold for a family of four (Mishel, Bernstein, \& Allegretto, 2005). Put another way, as recently as 2002, more than one in four (27.4\%) working parents with children in the U.S. earns less than $200 \%$ of the federal poverty level (Waldron, Roberts, \& Reamer, 2004). Although "poverty" is officially defined as under $100 \%$ of the federal threshold, scholars and policy makers contend that $200 \%$ of the poverty level is a minimum familysustaining income (Mishel, Bernstein, \& Boushey, 2003).

In addition, we know that children may manifest their parents' unemployment, low incomes, and/or depression or depressive symptoms as childhood depression or poor school performance (Gershoff, Aber, Raver, \& Lennon, 2007), although the parents in this research were predominantly female. Similarly, McLoyd, Jayaratne, Ceballo, and Borquez (1994) found that unemployment, work interruption, and poverty are associated with increased symptoms of depression and cognitive distress among the adolescent children of single African American mothers. These effects were both direct and indirect, via parenting practices and adolescents' perceptions. Taylor and colleagues (2000) found that economic and environmental stress impacted the parenting practices of African American and Puerto Rican mothers, which then influenced adolescents' grades in school.

Despite these valuable studies, we don't know whether contemporary fathers experience depressive symptoms or depression in relation to low-wage work or unemployment, and if they do, how. More broadly, we don't fully understand how the timing of parents' employment pathways, economic conditions, other life events or supports, and parents' depression or depressive symptoms affect family economic mobility. We also don't know how policies in parents' firms and in children's under-resourced urban schools might intersect with each other and with parents' depression or depressive symptoms to affect family mobility. These questions are lodged theoretically in the strand of economic sociology that emphasizes the 
social embeddedness of economic action (Granovetter, 1985), which is akin to but less systems-oriented than ecological perspectives in social work and other fields.

We look to ethnography to shed light on these more complex intersections. Typically, ethnographic research involves interpersonal engagement in naturalistic settings and is interactive rather than unitarily imposed (Burawoy et al., 1991). Ethnography is particularly relevant when how questions are paramount and when one studies processes, such as economic mobility, that develop and change over time (Yin, 2003). In this paper, we use data from field interviews, observation, administrative records, and from a community-based measure of adult depressive symptoms and depression that is embedded in the ethnographic inquiry to explore four phenomena relevant to the economic mobility of low-income families.

First, we look at timing and mobility-specifically, at how depressive symptoms and employment manifest at particular periods in the parents' employment pathways: the job training period, initial employment after training, and subsequent employment. Second, we look at the economy and mobility, as repeated administration of the depressive symptoms instrument enables us to compare parents' employment and depression relative to changing economic and labor market conditions. Third, we try to understand more deeply how the economy and mobility intersect by looking at parents' depression patterns over time in relation to their jobs, wages, life events, and resources. Fourth, we examine mobility as multiphenomenal by looking at how policies in parents' firms and children's schools intersect with parents' emotional and economic situations to affect family mobility. The longitudinal design and focus on both fathers and mothers offer a rare opportunity to better understand the complex experiences of people who are "working but still poor." We first describe the research design and characteristics of the families.

\section{Research Design}

The findings here result from analyses of a subset of data from a longitudinal, five-city ethnographic examination of low-income families and economic mobility (Iversen, 2002; Iversen \& Armstrong, 2006). The research period covers 1998 to mid-2003; the five research cities are Milwaukee, New Orleans, Philadelphia, St. Louis, and Seattle. The research team of nine consisted of a professor of social work (first author); locally based researchers from the disciplines of public administration (second author), cultural anthropology, applied anthropology and urban studies, and social work and social welfare; and a workforce development program director. The team's multiple disciplines afforded a rich range of both epistemological and methodological expertise.

The team accessed the 25 study families through the key parents' participation in a variety of welfare-to-work and job training programs that were affiliated with, but also functionally independent of, a national workforce development initiative (Fleischer, 2001; Gewirtz, 2001; Giloth, 2004). In addition to direct field contact with the families and their extended members for up to three and one-half years, we interviewed and observed at least 40 other auxiliaries per family-including workplace coworkers and managers, job training instructors, community and human service program administrators and staff, and children's child care and school personnel-for a total of at least 1,000 auxiliary contacts across the five cities. This inquiry is similar to what Marcus (1998) calls multisited ethnography and to what Burawoy (2003) describes as reflexive ethnography that is developed through synchronic comparisons in different spatial contexts (p. 646).

The research team administered the Center for Epidemiological Studies Depression Scale (CES-D) (Radloff, 1977; Radloff \& Locke, 1986) to each of the key parents at multiple time points to examine the relationship between depressive symptoms and the parents' mobility pathways. Depression and depressive symptoms are typically differentiated by time and severity. Depression is considered a mental health disorder with affective, physical, and cognitive components, lasting at least six months, which are generally identified through the professional administration of a clinical diagnostic measure. Depressive symptoms—such as sad mood, feelings of guilt, worthlessness, hopelessness or helplessness, psychomotor retardation, loss of appetite, and sleep disturbance (Radloff, p. 386) - are expected to vary over time and in relation to stressful life events. If pervasive or sustained, such symptoms may indicate the presence or risk of clinical depression.

The CES-D is a 20-item, noninvasive interview tool designed to evaluate individuals' current levels of depressive symptomatology in relation to levels within the general population (Radloff, 1977) and used increasingly in poverty and employment research. The scale has been validated across population groups (Aneshensel, Clark, \& Frerichs, 1983; Radloff; Tran, Ngo, \& Conway, 2003), although it may underassess depression among those whose symptoms are expressed somatically (Vega \& Rumbaut, 1991). The scoring range on the CES-D is zero to 60 . The average score in the general population is 9. A score of 16 , which demarcates the upper $20 \%$ of the score distribution in general population studies, is generally considered the cutoff level between nondepression and depression (Gotlib \& Cane, 1989; Radloff). Scores from 16 to 20 indicate mild depression; 21 to 30 , moderate depression; and 31 and over, severe depression (Gotlib \& Cane).

We administer the CES-D in the initial interview and in follow-up interviews approximately 6, 12, and 18 months to three years later. Per instrument design, individual CES-D scores are averaged across groups (Radloff \& Locke, 1986). We aggregate group scores here by gender. 
TABLE 1. Comparison of Key Parents With All Training Program Participants Locating Jobs, UI Recipients, and TANF Recipients: Selected Characteristics

\begin{tabular}{|c|c|c|c|c|}
\hline CHARACTERISTICS & $\begin{array}{l}\text { KEY PARENTS } \\
(N=25)\end{array}$ & $\begin{array}{c}\text { AlL Adults } \\
\text { LoCATING JobS IN } \\
\text { THE } 5 \text { CitIES } \\
(N=3999) \\
\text { PERCENT }\end{array}$ & $\begin{array}{l}\text { UI RECIPIENTS } \\
\text { IN 1998 } \\
(N=3907) \\
\text { PERCENT }\end{array}$ & $\begin{array}{c}\text { TANF } \\
\text { PARTICIPANTS IN } \\
2001^{c} \\
(N=268,575) \\
\text { PERCENT }\end{array}$ \\
\hline \multicolumn{5}{|l|}{ Age } \\
\hline Age 18 to 35 & 52 & 64 & $34.0(16-34)$ & $74(20-39)$ \\
\hline$<18,>35$ & 48 & 36 & & 7 (teens) \\
\hline \multicolumn{5}{|l|}{ Gender } \\
\hline Male & 36 & 50 & 56.0 & 10 \\
\hline Female & 64 & 50 & 44.0 & 90 \\
\hline \multicolumn{5}{|l|}{ Ethnicity } \\
\hline White, non-Hispanic & 4 & 11 & 66.0 & 30 \\
\hline Black & 72 & 70 & 13.0 & 39 \\
\hline Hispanic & 20 & 6 & 13.0 & 26 \\
\hline All Other & 4 & 12 & 9.3 & 4 \\
\hline \multicolumn{5}{|l|}{ Difficulty with English } \\
\hline Yes & 12 & 11 & & \\
\hline No & 88 & 89 & & \\
\hline \multicolumn{5}{|l|}{ Marital status ${ }^{d}$} \\
\hline Single & 72 & 77 & & 67 \\
\hline Married & 28 & 23 & & 12 \\
\hline \multicolumn{5}{|l|}{ School/highest grade completed } \\
\hline$<8$ & 0 & 2 & & 6 (0-6 years) \\
\hline $8-9$ & 8 & 6 & & 12 (7-9 years) \\
\hline $10-11$ & 28 & 24 & & 30 \\
\hline 12 & 44 & 41 & & 49 \\
\hline $13+$ & 20 & 27 & & 3 \\
\hline \multicolumn{5}{|l|}{ School certification } \\
\hline No certification & 16 & 12 & 18.0 & \\
\hline High school diploma or GED & 80 & 60 & 54.0 & \\
\hline $\begin{array}{l}\text { Technical/ Vocational/Occup. } \\
\text { Certificate/Associates } \\
\text { Degree }\end{array}$ & 40 & 24 & 16.0 & \\
\hline B.A. & 4 & 3 & 9.0 & \\
\hline Other & & & 3.0 & \\
\hline \multicolumn{5}{|l|}{$\begin{array}{l}\text { Family income at training } \\
\text { program enrollment }\end{array}$} \\
\hline$<\$ 11,999$ & 64 & 69 & & \\
\hline$\$ 12,000-\$ 24,999$ & 28 & 23 & & \\
\hline$>\$ 25,000$ & 8 & 7 & & \\
\hline \multicolumn{5}{|l|}{$\begin{array}{l}\text { Public assistance at workforce } \\
\text { program enrollment }\end{array}$} \\
\hline TANF + Other & 84 & 56 & & 100 \\
\hline No & 16 & 44 & & \\
\hline
\end{tabular}

${ }^{a}$ Hebert et al., 2002.

${ }^{\mathrm{b}}$ Needels, Corson, \& Nicholson, 2001

'U.S. Department of Health and Human Services, 2001

${ }^{\mathrm{d}}$ Total TANF does not equal $100 \%$ because some states switch two-parent families to other assistance programs.

The ethnographic interviews and observations, together with CES-D scores and program administrative data, help to suggest the direction of influence. Still, we use standard procedures to maximize the authenticity and credibility of the research (Denzin \& Lincoln, 2005; Padgett, 1998). Multiple sources and levels of data, methods, researchers and analysts-also called data, methodological, and investigator triangulation (Sands \& Roer-Strier, 2006)—increased reliability and led to "a more comprehensive picture of the phenomenon under study" (p. 239). Prolonged contact helped to minimize reactivity. Transcriptions of several hundred hours of audiotaped interviews helped to counteract researcher bias, and we checked facts and interpretation directly with the families before results were disseminated. While bias and other study limitations surely remain, we are reasonably confident that these steps reduce threats to the authenticity and credibility of the findings.

We conducted analyses throughout the study period to follow up on emergent themes and questions (Becker, 1998), ultimately organizing the interview and observational data around the key parent and his or her family. 
We used a qualitative research software program (NVIVO) for initial categorical and thematic coding, and we constructed an SPSS file to calculate frequencies and simple comparisons (ANOVA) on descriptive variables. The core analytic strategy was mining the multiple data sources, using a diachronic narrative approach, or telling a story through time, to construct narratives that document the range and complexity of the intersections among parents' employment, depression, children, the labor market, and family economic mobility. Short excerpts from these narratives, called "family stories," were adapted for this paper.

We define "low income" as individual annual wage income below 200\% of the federal poverty level (FPL) and "economic mobility" as the phenomenon of moving forward financially through paid work. All names are pseudonyms; family members selected their own pseudonyms, and the authors selected pseudonyms for firms.

\section{Description of the Key Parents}

We use administrative intake data from the welfare and workforce programs that the parents attended (Hebert et al., 2002) to describe the key parents (Table 1). Briefly, two thirds (16) are women and one third (9) are men. Sixty-six children reside with these parents, for an average of 2.6 children per family (not shown). The key parents are 32 years old on average and represent varied racial and ethnic backgrounds. One quarter are married and almost three quarters (18, or $72 \%)$ are single, although subsequent interviews reveal that 7 of the 18 live with a spouse or significant partner. Just over one third of these working parents dropped out of high school, although almost half of those later attained a General Educational Development (GED) certificate. The remaining two thirds completed 12 years of education, and one in five of those completed some postsecondary education or training. All were employed at some point before this job training, but their annual incomes generally fell below the federal poverty level due to part-time and/or part-year work, substandard or incomplete education, and/or family-related background challenges.

We compare the key parents to other low-income workers and working parents across the United States. Chi-square analyses using raw data on the selected demographic characteristics in Table 1 reveal that the 25 parents are similar to the universe of almost 4,000 economically disadvantaged men and women who located jobs after demonstration-affiliated training programs in the five research cities. We also compare the key parents to samples from Unemployment Insurance (UI) and Temporary Assistance for Needy Families (TANF) programs, because UI increasingly became the safety net for low-wage workers after welfare reform and because at least one parent in most of the families drew upon public assistance at some point in their adult lives. Given the size of the UI and TANF samples relative to the parent group, many comparisons are statistically but not substantively significant. For example, the study parents show higher postsecondary attainment than the TANF sample, but over two thirds of each group completed between 10 and 12 years of education. Overall, these comparisons suggest that the experiences of the families in this study may be generally shared by millions of other families across the United States.

The next sections address the four intersecting mobility-related phenomena outlined earlier.

\section{Timing and Mobility: Parents' Depression, Job Training, and Employment}

Evaluating depressive symptoms over time is important in employment research because certain periods are considered particularly challenging for new workers (Clymer, Roberts, \& Strawn, 2001). Despite this, assessment procedures and integrated services in welfare and workforce programs are limited (Iversen, 1998; Kramer, 2001; Lennon et al., 2001).

\section{In Training}

During training, the mothers scored in the depression range (average $=20)$, but the fathers did not (average $=$ 6). Because completing a training program can be pivotal to a career pathway, the gender difference at this time point was a concern. Although mothers and fathers have similar backgrounds, the ethnographic data suggest that during training, making new child care, after-school, transportation, and summer arrangements weighed more heavily on mothers than on fathers. At the same time, program flexibility and case manager moral support seemed to mediate training continuation, despite depression-level stress, as Isabell Smith's experience typifies:
"L" was my original case manager, she was so awesome. I was trying to do everything and I was moving, getting my son back for the first time, supposed to start school at the same time and I called her up freaking out. She was great, and she told me,
“Girl, you are nervous, but don't worry about it, school will still be there; you can do the one in June." (Isabell Smith, Seattle)

\section{First Six Months on the Job}

During the first six months on the job, neither the mothers nor the fathers are depressed (mothers' average $=11$; fathers' average $=6$ ). At this point, the parents earn higher wages than ever before, from both full-time, year-round employment and the entrée into jobs and industries that are higher-paying than those they could access before training. In addition, they are eligible for a year of 
postemployment services-such as emergency funds, moral support, and re-employment guidance-from their welfare or workforce program.

\section{Six to 12 Months on the Job}

After the first six months of work, the story of depression and employment gets more complicated, as Clymer and colleagues (2001) predict (only mothers' data for this period). Their average score of 15 nears the level of 16 that signifies mild depression and is well above the population average of 9. The latter part of the first vulnerable transition year of balancing work and family demands also coincides with the discouraging realization that their better wages are still insufficient, as Tasha Jones's story illustrates.

With an annual income of $\$ 20,000$ in a machine operator position at Manufacturing Company in Milwaukee, 23-year-old Tasha Jones believed she was making enough money for her family of two preschool children. However, applying the Self-Sufficiency Standard for Wisconsin (Pearce, 2000), a more contextual analysis of income adequacy than the federal poverty level, to her earnings corroborated Tasha's growing realization that, as a single mother, she needed an annual income of about $\$ 30,000$ to support her family.

Tasha's department supervisor similarly doubted that the company's wage scale was adequate for a person like Tasha:

\section{In my opinion, a husband and wife have to both work if they're making these wages- $\$ 11$ or $\$ 10$ an hour. That gives you roughly $\$ 20,000$ a year. And a woman with two kids is not having an easy time on that. I think you need about $\$ 30,000$ for one person to raise two kids. (Department Supervisor, Manufacturing Company, Milwaukee)}

The average post-training wage across the training programs was $\$ 9.13$ per hour in 2000 (Hebert et al., 2002). Only one key parent's post-training wage came close to $200 \%$ of the federal poverty level.

Even so, extending postemployment services beyond the first year of work may prevent cumulative challenges from derailing parents' work efforts and emotional wellbeing, as Maya Vanderhand's story illustrates.

Maya's workforce program case manager called just at the point that Maya needed help with moving expenses and a rental deposit for a new and safer apartment for her family. This case manager perceptively recognized that the one-year mark was one of particular vulnerability, often the end of a "honeymoon period" wherein old patterns surface and threaten job retention or child care arrangements deteriorate. The case manager thus continued with her new workers through the transition. In Maya's case, the one-year mark fueled her desire to improve the family's living situation, which was economically feasible until her husband lost his job in the middle of the family's move.
In addition to the case manager's emotional support during this crisis, the program offered gas vouchers and a clothing allowance that Maya used for work shoes-a job-related expense that Maya regularly subsumed in favor of her children's needs:

You need a pair of shoes because with kids it is really hard. I buy the kids' first but then when you really, really need it, it is like geez ... you got to squeeze things here and there, and so they help me with some shoes and I made it work where I could get some tights and shoes and get some sales out there. (Maya Vanderhand, Seattle)

It would probably also have been helpful if Maya's program had been structured to extend its job services to her husband, but individuals, not families, are considered service recipients.

\section{One to Three Years on the Job}

In the second and third years of labor market attachment, the mothers' depression score lowers again slightly (average year $2=13$; average year $3=12$ ), while the fathers' score increases (average year $2=15$; no data year 3 ). The ethnographic data suggest that by the second year of work, many of the mothers iron out their transition challenges and some make job changes that result in higher incomes. Fathers change jobs during these years more often than mothers do, which seemed to be associated with increased stress. Moreover, most parents are no longer eligible for postemployment services from their training program, although a few mothers located alternative community resources.

Other parents, such as Ayesha Muhammad, a 45-yearold, divorced Philadelphia mother of five, wish their program's supports had been longer. Ayesha's welfare-to-work program partnered with a well-established temp agency through which she landed a job in a financial services company that turned into a full-time position with benefits and a richly structured and supported internal career ladder. Despite Ayesha's long prior career in health care, she considers program follow-up important:

They were supposed to have an after-care program to deal with the graduates. I haven't heard from anyone there in months. I told them I was on a temp job. I didn't hear anything else from them ... The after-care program needs to be more intense. Really and truly, I'd like them to...call us up and find out what's going on. Find out any support we need-like childcare. Help us get what we need from employers-especially financially. (Ayesha Muhammad, Philadelphia) 


\section{Three or More Years on the Job}

In contrast, after more than three years of working, mothers and fathers both score at the mild depression level ( mothers' average $=20$; fathers' average $=19$ ). The ethnographic data suggest that this rise in depressive symptoms is associated with persistently insufficient incomes and the lengthy economic downturn following the 2001 recession. We turn to these economic influences next.

\section{The Economy and Mobility: Parents' Depression, Employment, and Labor Market Conditions}

Recent restructuring in the labor market-particularly the increase in temporary and contingent work (Osterman, Kochan, Locke, \& Piore, 2001), downsizing or reduction in the workforce (Baumol, Blinder, \& Wolff, 2003), and the reduction or elimination of internal career ladders (Osterman, 1999) — threaten employment tenure and advancement, especially at the low-wage end of the labor market. The families in this research seemed to experience this turbulence with increasing levels of depressive symptoms.

Analyzing CES-D scores now by calendar year, the average score of both mothers and fathers falls below the depression indicator of 16 in each of the field research years before 2003. In 2003, however, the mothers' score increases to 18 , the mild depression level, and the fathers' score increases to 21 , the moderate depression level. Prospective administration of the CES-D thus suggests that economic turbulence contributes to parental depression. In fact, the final CES-D administration in 2003 coincides with longer spells of unemployment and significant wage reductions for parents who become reemployed. Moreover, even for the few parents whose incomes increase, they generally increase just enough to make them ineligible for work supports-such as housing, food, and child care subsidies-but not enough to meet their families' day-to-day needs, as Mr. Blessed's story showed earlier.

Interpreting the depression scores further through the ethnographic lens, the fathers' higher score in 2003 is associated with sustained job loss and volatility in the industries in which most fathers worked, such as manufacturing and construction. Although the mothers were more likely to be employed in industries that fare better during economic downturn, such as nursing and clerical services, the depression score of mothers employed in construction and manufacturing in 2003 resembles the higher score of the fathers. Moreover, the persistence of the economic downturn into 2003 and beyond also affected the traditionally employed women, as evidenced by the almost doubling of the mothers' score from 10 in 2002 to 18 in 2003. Strikingly, the fathers' score tripled over the same period, from 7 to 21 . We use the ethno- graphic data to further explore why the depression scores didn't rise until two years after the 2001 recession began and what patterns emerge within the group as a whole.

\section{Parents' Depression, Employment, and Life Events: Patterns Over Time}

Although the parents' lives are remarkably similar, they exhibit three different patterns of depression and nondepression: (a) not depressed during the field research period; (b) depression-level symptoms over the entire period; and (c) depression-level symptoms over part of the period in two distinct patterns: not depressed to depressed, and depressed to not depressed. The traditional correlates of depression among low-income parents-such as low education, marital stress, or higher than average number of children-do not appear to explain the different patterns of depressive symptoms among these working parents. In contrast, the ethnographic data suggest that wages and certain policy and instrumental work supports are particularly strong mediators of the parents' life and job stressors.

\section{Not Depressed During Field Research Period}

The first group of parents ( 6 mothers; 5 fathers) scores in the nondepression range throughout the field research period, despite the usual challenges of inadequate incomes and the less frequent but serious challenges of perceived workplace racism and underemployment. Having a job with wages that reach or move toward $200 \%$ FPL, or holding a second job that is perceived as "having advancement potential," seem to be strong mediators. Regular and reliable family support, particularly in the form of child care or temporary housing, also seems a strong mediator. That said, this research cannot rule out coterminous biological invulnerability.

\section{Depression-Level Symptoms Over Entire Field Research Period}

The second group of parents (mothers only, $n=4$ ) exhibits depression-level symptoms over the entire field research period, with the exception of one mother's several-month respite in which she experiences supports similar to parents in the not depressed group: her partner is employed, thus family earnings temporarily exceed $200 \%$ FPL; she is eligible for unemployment insurance after her post-training job ends; she qualifies for state-sponsored web design training; her family life is "more regular"; and she and her children remain eligible for supportive services from several community providers. For the most part, however, even though these women's post-training jobs initially provide higher wages than earlier jobs, over time the women incur layoff, inadequate hours, firm closure, or termination. As a result, their potential annual earnings, which would have exceeded the poverty level if 
the job had lasted for a full calendar year, result in actual annual earnings that are dramatically below poverty level. These mothers also report a higher incidence of past abuse, clinical depression, and homelessness than do parents in either of the other two groups, which suggests preexisting vulnerability to emotional stress that may be exacerbated by employment challenges, especially if available work and family supports aren't adequate.

\section{Depression-Level Symptoms During Part of Field Research Period}

The third group of parents shows depressive symptoms during part of the field research period in two distinct patterns that do not appear to differ by gender. One subgroup of three mothers and three fathers is not depressed at the time the first and second CES-Ds are administered, which coincides with the first post-training job and active postemployment services, but exhibits signs of depression over time. Their initial "not depressed" scores may be anomalous relative to their past history, but the ethnographic data suggest that depression-level scores emerge alongside workplace and environmental stressors. The incomes of parents in this subgroup are severely reduced through layoff, industry downturn, or lower wages and reduced hours in jobs that follow their first post-training position, and several partner relationships dissolve. Tisha Shanks's downward cascade is typical among this subgroup, as her story excerpt describes:

\footnotetext{
Thirty-three year old Tisha Shanks, mother of three school-age youth, survived six previous layoffs in her assembly position at Steel Company, her second job after manufacturing training, but succumbed to the seventh in May 2001. Ten months later Tisha finally located another manufacturing job that paid $\$ 9.80$ an hour, which was almost $\$ 3$ an hour less than her final wage at Steel Company. Because of the lower wage and separation from her income-contributing partner, Tisha lost the house that she'd bought after her release from prison, which was carefully selected to ensure neighborhood safety and good schools for her children. Ironically, Tisha had just been awarded a "Justice Award of Honor" for her contributions to a harm reduction program sponsored by a local community organization. (Tisha Shanks, Milwaukee)
}

The second subgroup of three mothers and one father shows signs of depression at the first two CES-D administration periods, concurrent with on-the-job injuries, poor matches with the job environment, or the inability to utilize their training because of industry slowdown. Over time, these parents change jobs; their family and community supports, especially in housing, seem to buffer environmental stress; worksites accommodate their injuries; and some of their incomes move closer to
200\% FPL. These events seem notably associated with moving from depressed to not depressed. In one contradictory case, however, Mike Jeremy's move from depressed to not depressed was due to leaving a full-time job with benefits at Equipment Manufacturer for a parttime parking attendant job, even though it offered one third less pay and no benefits. At the same time, he and his wife had their second child, which increased expenses. Mike's story illustrates a decision that employers or case managers often characterize as lack of motivation, but that Mike, a 42-year-old refugee from a war-torn African country, views as better for his family.

Mike was relieved to be working in a low-stress capacity and only 30 hours per week: "If you aren't feeling well, it's good not to work so hard." However, he acknowledged ruefully that while Equipment Manufacturer made employees work hard, it had provided him with a higher salary and health benefits. At the same time, workplace conditions conflicted with his family priorities:

I was sick. The day before I quit, I had another accident. It's hard to put screwdrivers in; sometimes the hand turns. I hurt my hand and they took me to the first aid office. I couldn't stay there any longer. My family is my first priority. (Mike Jeremy, Seattle)

The notion of "conflict-bound rationality" (Nee, 1998) helps to explain actions like Mike's that appear irrational but have a coherent logic in their particular contexts. As Brinton and Nee (1998) hold, "The actions of social actors are always in principle understandable, provided we are sufficiently informed about their situation" (p. 4).

These examinations of how training and time on the job, the economy, and life events are associated with family economic mobility reveal that depression and depressive symptoms are highest among parents when their incomes are lowest and their policy, program, or personal supports and resources are fewest. When parents achieve family-sustaining incomes that reach or exceed twice the federal poverty threshold, depressive symptoms recede or do not reach depression level. Adequate policy, family, and service supports move families toward such incomes. Overall however, periods of sufficient income are rare and short-lived, especially during a recession economy, thus the emotional and financial security of many of these working but lowearning parents remains precarious. As such, the stability and well-being of their children remain precarious as well (Weissman et al., 2006). The ubiquity and persistence of children's school problems in this research draws attention to a special case of intersecting institutions that we discuss next. 


\section{Parents' Firms and Children's Schools: A Special Case of Intersecting Institutions}

A surprising finding in this research was the fact that policies in children's schools intersect with policies in parents' firms to influence family economic mobility. Children's challenges in under-resourced urban schools are a perpetual part of the depression-related environment for low-earning parents. Ethnography reveals how firm and school policies and practices clash to jeopardize mobility and that community supports and social services can mediate, but only partially.

For example, Isabell Smith utilized her workforce training program's community support network, which actively incorporates her welfare caseworker, to retrieve one son from foster care and competently care for him and his infant brother after her year of residential drug rehabilitation. Isabell's developmentally disabled sons thrived in the therapeutic child care agency she located for their preschool years and eventually entered regular school. However, heightened job-related stress and depression-level symptoms, likely set in motion during Isabell's childhood of abuse and exacerbated now by her firm's policies, constrain her children's school progress, which, in turn, constrains her mobility progress, as this story excerpt illustrates.

Within the first two months of post-training employment as a customer service representative at a high-tech retailer, Isabell's work schedule changed three times. By late November, she was working 55 "mandatory" hours per week, over ten hours per day on the phones, with mostly disgruntled customers. These first months of work had a significant impact on Isabell's preschool-age children, as she describes:

I really took it too much to heart, being screamed at on a daily basis, all day long, and it affected everything. It affected my family, plus I was going to work at 6 a.m. and not coming home until 8 or 9 that night. So I would leave the house and the kids were sleeping and I would come home and they were on their way to bed or in bed. (Isabell Smith, Seattle)

The director of the children's therapeutic preschool program confirmed the tumult of this period:

December was particularly difficult. We observed the stress in the children, who were more aggressive in the classroom, and in Isabell who did not have as much time to communicate with us about the children. (Director, Therapeutic Childcare Agency, Seattle)

While Isabell's network of supports enabled her to remain employed, they did not address the extreme variability in hours at Isabell's firm. As a result, three and one half years after our first meeting with the family, Isabell's older son still exhibited some behavior problems in the school setting. By then, Isabell worked at a new office job that allowed more flexibility to meet her children's needs, but did not offer advancement opportunity.

In another example, Lynn Walker's layoff, depressionlevel symptoms, homelessness, relocation to another city rather than live in St. Louis with the abusive father of her children, and the new elementary school's policies intersected to affect the family's mobility, as her story describes.

After the Walker family moved to [city], they contended with the cumulative stressors of living in a domestic violence shelter, moving again to a public housing environment, new and more demanding schools for the children, and several job changes for Lynn. Lynn eventually landed a promising job in a library, but although her boss said he would "work with" her if she had to alter her work hours to meet family obligations, the library's official time policies were rigid. The misalignment between Lynn's workplace and the children's elementary school was graphically illustrated when the school nurse called Lynn at work to report that 6-year-old Diamond had a 102-degree fever, as Lynn related:
My supervisor had just stepped out-I told the school I couldn't up and leave and jeopardize my job; I'd need to confirm permission to leave. The school nurse said, "No, you need to come get your child now. She's contagious. You're putting your child in jeopardy-I will call DSS and report you as an unfit parent." I told them, "I don't even whoop my children." She said, "You need to get up off your can and get your daughter-she's sick; I'm not a babysitter." So I went to another supervisor-the one above my boss-and he gave the OK to leave. My boss didn't like what I did-go above him, but he understood when I told him about the school's threats. I'm writing a letter to the Board of Education about the school's disregard of the importance of a single parent's work to the welfare of the children. (Lynn Walker, city outside St. Louis)

These and many similar examples in the ethnography suggest that the association between parents' depression or depressive symptoms, parents' employment, children's schools, and family economic mobility is cumulative and reciprocal. The policies and priorities of children's schools, families, and parents' firms are often not aligned. When a parent's condition or situation affects children such that their school behavior or performance worsens, schools often pressure parents to remediate. Such pressure may increase the parents' stress levels enough to result in depression-level symptoms and/or sustain existing depressive symptoms and threaten the parent's job 
security. At the same time, the family's children are also vulnerable to depression or other behavioral manifestations of family stress. Although the key parent sample in this report is small, the detailed ethnographic findings suggest a broad landscape for researchers, practitioners, and policy makers to consider further.

\section{Conclusions and Implications}

Sizable numbers of low-wage working mothers are vulnerable to depression or symptoms of depression that may interfere with work efforts and employment tenure. This longitudinal ethnographic research identifies that fathers, either as trainees or new workers, also experience jobrelated depression and depressive symptoms. Yet most welfare and workforce programs inconsistently identify women's needs and are even less likely to identify men's experiences. Stigma, the predominance of individual rather than family-inclusive assessment procedures, and inadequate staff knowledge about the multiple and varied manifestations of depression impede adequate identification and remediation. In contrast, treatment of parental depression is found to increase the likelihood of continued employment (Lennon et al., 2001) and improve child well-being (Weissman et al., 2006). Ethnographic findings about how parents' depression, job pathways, economic conditions, life events, and other institutions, such as children's schools, intersect to affect family economic mobility suggest the following refinements of welfare and workforce program practices and policies.

At the program level, welfare and workforce program case managers need to learn how to identify the broad range of symptoms implicated in depression, as well as how they may manifest differently by gender (Mayo Clinic, 2004). Program staff members also need to screen men, as well as women, for depressive symptoms. Male job seekers, in particular, do not readily disclose such symptoms, yet screening embedded in a comprehensive assessment may lead to earlier treatment and resolution of problems that can surface in training or at work (Kramer, 2001). Although case managers and job coaches are typically not licensed clinicians, many of them are social workers or other experienced service providers who can easily be trained to administer and score a nonclinical tool such as the CES-D as part of the assessment process. In welfare and workforce development venues, however, we recommend that the CES-D be used in person in the context of comprehensive assessment, rather than as a self-report tool.

Accordingly, interview material together with CES-D scores can be used to identify the vulnerability level of groups of job seekers and allow program staff to triage supportive services to those with the greatest needs, especially those with limited family and social networks. The CES-D can also be re-administered during the transition from training to employment and during the first year or so of work, thus serving as an alert about job retention among new or returning workers. Ideally, a job seeker's partner or spouse could also be assessed for depression or depressive symptoms, as their health and employment experiences can strongly influence a job seeker's employment outcomes.

Also at the program level, because CES-D scores are analyzed in the aggregate by group or cohort, welfare and workforce programs, or other social service organizations, can use the scores to inform program planners about the changing needs of the workforce population, which can then lead to tailored service design, staff hiring, and staff development. For example, one workforce program implemented an integrated service model whereby staff members receive intensive training in mental health from area specialists. An innovative result of this alliance is that staff members now use the rhetoric of "stress management," rather than mental health, to counteract potential stigma.

Toward further system-level service integration, mental health specialists can work collaboratively on-site with welfare or workforce specialists. In turn, a multidisciplinary team can educate human resource staff and supervisors in firms about depressive symptoms and depression to mediate the employment pathways of new workers. Such interinstitutional collaboration seems particularly urgent, given Stewart, Ricci, Chee, Hahn, and Morganstein's (2003) report that productivity loss in firms is due more to depression-related decreased performance at work than to absenteeism. According to them, $80 \%$ of the $\$ 44$ billion annual cost of lost productivity is associated with workers who are diverted on the job by depressive symptoms.

Also at the system level, welfare and workforce programs and firms need to recognize that school systems are vital actors in family mobility. Especially considering the productivity loss associated with depressive symptoms, firms could profitably implement more flexible time-off policies to help parents meet their children's needs. The reverse is equally true. A child's poor or variable academic performance may be a symptom of depressive stress in either child or parent, particularly if the family's income is insufficient (Duncan, Yeung, Brooks-Gunn, \& Smith, 1998; Duncan et al., 2001; Elder, 1998; McLeod \& Shanahan, 1996; Morris, Gennetian, \& Duncan, 2005; Sarafolean, 2000). Thus, school and preschool staff need to be vigilant about identifying and addressing the associations between parents' work policies and stresses, children's school performance, and school policies and practices. At present, such awareness on the part of both school and business institutions is virtually nonexistent.

To illustrate, during the 120 days that our research team spent in the children's schools, not one teacher or administrator commented positively about a parent's employment or acknowledged the stresses that children's parents 
face regularly in low-wage work, such as loss of pay when schools summon parents for conferences and their inability to participate in school trips and meet other parentinvolvement demands because they need to hold two (or more) jobs to make an above-poverty income. Similarly, only one out of the 74 firms in which the parents worked in our research offered an official flextime policy whereby a parent could attend a school conference and make up the work afterward, without losing wages.

Finally, this research underscores the importance of family economic security. Thus, national policy efforts are also indicated. Absent significant wage redistribution in firms, returning workers, like many of the families here, need to have longer-term access to work-fostering subsidies, such as the Earned Income Tax Credit (EITC), unemployment insurance, and housing and child care support. More generally, the study parents' vulnerability, even five or more years into this phase of employment, suggests that longer follow-up support than is mandated by welfare and workforce policies may enhance the progress and well-being of families that are at risk of depression or whose depressive symptoms interfere with work success and/or children's school performance.

Without multilevel, multi-institutional attention and larger-scale research on the phenomena revealed in this ethnography, the potential economic mobility of many working parents and their children may be sacrificed.

\section{References}

Ahluwalia, S. K., McGroder, S. M., Zaslow, M. J., \& Hair, E. C. (2001). Symptoms of depression among welfare recipients: A concern for two generations. Child Trends Research Brief. Washington, DC: Child Trends.

Aneshensel, C. S., Clark, V. A., \& Frerichs, R. R. (1983). Race, ethnicity, and depression: A confirmatory analysis. Journal of Personality and Social Psychology, 44, 385-398.

Baumol, W. J., Blinder, A. S., \& Wolff, E. N. (2003). Downsizing in America: Reality, causes, and consequences. New York: Russell Sage Foundation.

Becker, H. S. (1998). Tricks of the trade. Chicago: University of Chicago Press.

Brinton, M. C., \& Nee, V. (1998). The new institutionalism in sociology. Stanford, CA: Stanford University Press.

Burawoy, M. (2003). Revisits: An outline of a theory of reflexive ethnography. American Sociological Review, 68, 645-79.

Burawoy, M., Burton, A., Ferguson, A. A., Fox, K. J., Gamson, J., Gartrell, N., et al. (1991). Ethnography unbound: Power and resistance in the modern metropolis. Berkeley: University of California Press.

Clymer, C., Roberts, B., \& Strawn, J. (2001). States of change. Philadelphia: Public/Private Ventures.

Danziger, S., Corcoran, M., Danziger, S., Heflin, C., Kalil, R., Levine, J., et al. (1998). Barriers to the employment of welfare recipients. Ann Arbor: University of Michigan, Poverty Research \& Training Center.

Denzin, N. K., \& Lincoln, Y. S. (2005). Introduction. In N. K. Denzin and Y. S. Lincoln (Eds.), Handbook of Qualitative Research (3rd ed., pp. 1-32). Thousand Oaks, CA: Sage.

Duncan, G. J., Dunifon, R. E., Doran, M. B. W., \& Yeung, W. J. (2001). How different are welfare and working families? And do these differences matter for children's achievement? In G. J. Duncan \& P. L. Chase-Lansdale (Eds.), For better and for worse (pp. 103-131). New York: Russell Sage Foundation.
Duncan, G. J., Yeung, W. J., Brooks-Gunn, J., \& Smith, J. R. (1998). How much does childhood poverty affect the life chances of children? American Sociological Review, 63(3), 406-423.

Elder, G. (1974). Children of the Great Depression. Chicago: University of Chicago Press.

Elder, G. H., Jr. (1998). The life course as developmental theory. Child Development, 69(1), 1-12.

Fleischer, W. (2001). Extending ladders: Findings from The Annie E. Casey Foundation's Jobs Initiative. Baltimore: The Annie E. Casey Foundation.

Gershoff, E. T., Aber, J. L., Raver, C. C., \& Lennon, M. C. (2007). Income is not enough: Incorporating material hardship into models of income associations with parenting and child development. Child Development, 78(1), 70-95.

Gewirtz, S. (2001). Retaining low-income residents in the workforce: Lessons learned from The Annie E. Casey Jobs Initiative. Policy Update. Baltimore: The Annie E. Casey Foundation.

Giloth, R. (Ed.). (2004). Workforce intermediaries for the twenty-first century. Philadelphia: Temple University Press in association with The American Assembly, Columbia University Press.

Gotlib, I. H., \& Cane, D. B. (1989). Self-report assessment of depression and anxiety. In P. C. Kendall \& D. Watson (Eds.), Anxiety and depression (pp. 131-169). New York: Academic Press.

Granovetter, M. (1985). Economic action and social structure: The problem of embeddedness. American Journal of Sociology, 91, 481-510.

Hebert, S., Welch, D., St. George, A., Berrien, J., Schwartz, A., Mueller, E., et al. (2002). AECF Jobs Initiative: Evaluation of the capacity building phase, April 1997-2000. Boston: Abt Associates, and New York: The New School University.

Iversen, R. R. (1998). Occupational social work for the 21st century. Social Work: Special Centennial Issue, 43, 551-566.

Iversen, R. R. (2002). Moving up is a steep climb. Baltimore: The Annie E. Casey Foundation.

Iversen, R. R., \& Armstrong, A. L. (2006). Jobs aren't enough: Toward a new economic mobility for low-income families. Philadelphia: Temple University Press.

Kessler, R. C., Berglund, P., Demler, O., Jin, R., Koretz, D., Merikangas, K. R., et al. (2003). The epidemiology of major depressive disorder: Results from the National Comorbidity Survey Replication (NCS-R). Journal of the American Medical Association, 289, 3095-3105.

Kramer, F. D. (2001). Screening and assessment for physical and mental health issues that impact TANF recipients' ability to work. Welfare Information Network Issue Notes, 5, 1-12.

Lennon, M. C., Blome, J., \& English, K. (2001). Depression and lowincome women: Challenges for TANF and welfare-to-work policies and programs. New York: Columbia University, Mailman School of Public Health, National Center for Children in Poverty.

Marcus, G. E. (1998). Ethnography through thick and thin. Princeton, NJ: Princeton University Press.

Mayo Clinic (2004). Male depression: Don't ignore the symptoms. Retrieved July 8, 2006, from www.mayoclinic.com/print/maledepression/MC00041/METHOD=print

McLeod, J. D., \& Shanahan, M. J. (1996). Trajectories of poverty and children's mental health. Journal of Health and Social Behavior, 37, 207-220.

McLoyd, V., Jayaratne, T. E., Ceballo, R., \& Borquez, J. (1994). Unemployment and work interruption among African American single mothers: Effects on parenting and adolescent socioemotional functioning. Child Development, 65, 562-589.

Mishel, L., Bernstein, J., \& Allegretto, S. (2005). The state of working America 2004/2005. Ithaca, NY: Cornell University Press.

Mishel, L., Bernstein, J., \& Boushey, H. (2003). The state of working America 2002/2003. Ithaca, NY: Cornell University Press.

Morris, P. A., Gennetian, L. A., \& Duncan, G. J. (2005). Effects of welfare and employment policies on young children: New findings on policy experiments conducted in the early 1990s. Social Policy Report, 19(2), 1-18. 
Nee, V. (1998). Sources of the new institutionalism. In M. C. Brinton \& V. Nee (Eds.), The new institutionalism in sociology (pp. 1-16). Stanford, CA: Stanford University Press.

Needels, K., Corson, W., \& Nicholson, W. (2001). Left out of the boom economy (Report \#8573). Princeton, NJ: Mathematica Policy Research.

Osterman, P. (1999). Securing prosperity. Princeton, NJ: Princeton University Press.

Osterman, P., Kochan, T. A., Locke, R., \& Piore, M. J. (2001). Working in America: A blueprint for the new labor market. Cambridge, MA: MIT Press.

Padgett, D. K. (1998). Qualitative methods in social work research: Challenges and rewards. Thousand Oaks, CA: Sage.

Pearce, D. (2000). The Self-Sufficiency Standard for Wisconsin. Madison, WI: Education Fund of the Wisconsin Women's Network.

Radloff, L. S. (1977). The CES-D scale: A self-report depression scale for research in the general population. Applied Psychological Measurement, 3, 385-401.

Radloff, L. S., \& Locke, B. Z. (1986). The Community Mental Health Assessment Survey and the CES-D scale. In M. M. Weissman, J. K. Myer, \& C. E. Ross, (Eds.), Community surveys of psychiatric disorders (pp. 177-189). New Brunswick, NJ: Rutgers University Press.

Sands, R. G., \& Roer-Strier, D. (2006). Using data triangulation of mother and daughter interviews to enhance research about families. Qualitative Social Work, 5(2), 237-260.

Sarafolean, M. H. (2000). Depression in school-age children and adolescents: Characteristics, assessment and prevention. A Pediatric Perspective, 9(4), 1-5. [Newsletter of Gillette Children's Specialty Healthcare, St. Paul, MN]

Stewart, W. F., Ricci, J. A., Chee, E., Hahn, S. R., \& Morganstein, D. (2003). Cost of lost productive work time among U.S. workers with depression. Journal of the American Medical Association, 289, 3135-3144.

Taylor, R. D., Jacobson, L., Rodriguez, A. U., Dominguez, A., Cantic, R., Doney, J. et al. (2000). Stressful experiences and the psychological functioning of African-American and Puerto Rican families and adolescents. In R. D. Taylor \& M. C. Wang (Eds.), Resilience across contexts: Family, work, culture, and community (pp. 35-53). Mahwah, NJ: Lawrence Erlbaum Associates.

Tran, T. V., Ngo, D., \& Conway, K. (2003). A cross-cultural measure of depressive symptoms among Vietnamese Americans. Social Work Research, 27, 56-64.
U.S. Department of Health and Human Services (2001). Fiscal year 2001: Characteristics and financial circumstances of TANF recipients. Washington, DC: Author, Administration for Children \& Families. Retrieved August 18, 2004, from www.acf.dhhs.gov/programs/ofa/character/FY2001/characteristics.htm

Vega, W. A., \& Rumbaut, R. G. (1991). Ethnic minorities and mental health. American Review of Sociology, 17, 351-383.

Waldron, T., Roberts, B., \& Reamer, A. (2004). Working hard, falling short: America's working families and the pursuit of economic security. Baltimore: The Annie E. Casey Foundation.

Weissman, M. M., Pilowsky, D. J., Wickramaratne, P. J., Talati, A., Wisniewski, S. R., Fava, M., et al. (2006). Remissions in maternal depression and child psychopathology: A STAR ${ }^{\star} \mathrm{D}$-child report. Journal of the American Medical Association, 295(12), 1389-1398.

Yin, R. K. (2003). Case study research: Design and methods (3rd ed.). Thousand Oaks, CA: Sage.

Roberta Rehner Iversen, PhD, MSS, LSW, is associate professor, School of Social Policy \& Practice, University of Pennsylvania. Annie Laurie Armstrong, MPA, is president, Business Government Community Connections, Seattle, Washington. Iversen and Armstrong's recent book, Jobs Aren't Enough: Toward a New Economic Mobility for Low-Income Families (2006, Temple University Press), tells the full story about economic mobility among families that are working but still poor. Correspondence regarding this article may be sent to the first author at riversen@sp2.upenn.edu or University of Pennsylvania, School of Social Policy \& Practice, 3701 Locust Walk, Philadelphia, PA 19104-6214.

Authors' note. This research was conducted under independent grants to the first author from The Annie E. Casey Foundation. The contents of this paper do not necessarily reflect the opinions of the Foundation. The authors deeply appreciate the helpful comments from the anonymous reviewers.

Editor's note. A review of the book noted above appears at the end of this issue.

Manuscript received: August 16, 2006

Revised: April 1, 2007

Accepted: April 15, 2007 